\title{
Waves and variants of SARS-CoV-2: understanding the causes and effect of the COVID-19 catastrophe
}

\author{
Vikram Thakur ${ }^{1,2} \cdot$ Shivam Bhola $^{3} \cdot$ Pryanka Thakur $^{1} \cdot$ Sanjay Kumar Singh Patel ${ }^{4} \cdot$ Saurabh Kulshrestha ${ }^{3}$. \\ Radha Kanta Ratho ${ }^{1}$. Pradeep Kumar ${ }^{3}$
}

Received: 16 September 2021 / Accepted: 16 November 2021 / Published online: 16 December 2021

(c) The Author(s), under exclusive licence to Springer-Verlag GmbH Germany 2021, corrected publication 2022

\begin{abstract}
The coronavirus disease-19 has left a permanent mark on the history of the human race. Severe acute respiratory syndrome coronavirus-2 is a positive-sense single-stranded RNA virus, first reported in Wuhan, China, in December 2019 and from there took over the world. Being highly susceptible to mutations, the virus's numerous variants started to appear, and some were more lethal and infectious than the parent. The effectiveness of the vaccine is also affected severely against the new variant. In this study, the infectious mechanism of the coronavirus is explained with a focus on different variants and their respective mutations, which play a critical role in the increased transmissibility, infectivity, and immune escape of the virus. As India has already faced the second wave of the pandemic, the future outlook on the likeliness of a third wave with respect to the Indian variants such as kappa, delta, and Delta Plus is also discussed. This review article aims to reflect the catastrophe of the variants of SARS-CoV-2 and the possibility of developing even more severe variants in the near future.
\end{abstract}

Vikram Thakur, Shivam Bhola and Pryanka Thakur contributed equally to this work.

Radha Kanta Ratho

rathopgi@yahoo.com

$\triangle$ Pradeep Kumar

pradeep.kumar@shooliniuniversity.com

1 Department of Virology, Postgraduate Institute of Medical Education and Research (PGIMER), Chandigarh 160012, India

2 Viral Regional Diagnostic Laboratory (VRDL), Government Medical College, Patiala 147001, India
3 Faculty of Applied Sciences and Biotechnology, Shoolini University of Biotechnology and Management Sciences, Solan, India

4 Department of Chemical Engineering, Konkuk University, Seoul 05029, South Korea 


\section{Graphical abstract}

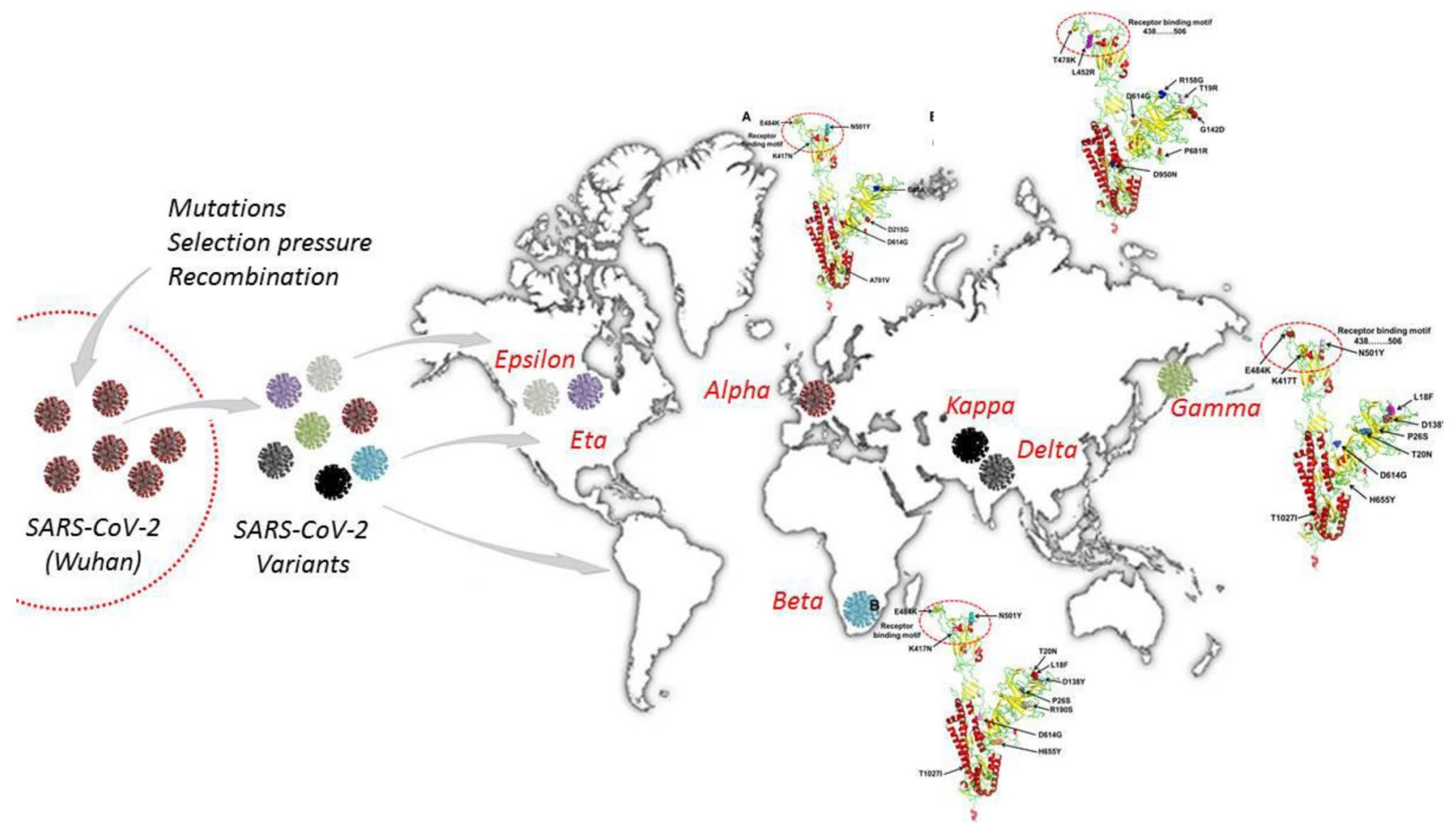

Keywords SARS-CoV-2 $\cdot$ Variants $\cdot$ Waves $\cdot$ Mutations $\cdot$ Immune evasion $\cdot$ Vaccines

$\begin{array}{ll}\text { Abbreviations } & \\ \text { COVID-19 } & \text { Coronavirus disease-19 } \\ \text { SARS-CoV-2 } & \begin{array}{l}\text { Severe respiratory syndrome } \\ \text { coronavirus-2 }\end{array} \\ \text { WHO } & \text { World Health Organization } \\ \text { ORF } & \text { Open reading frame } \\ \text { ACE-2 } & \text { Angiotensin-converting enzyme-2 } \\ \text { NTD } & \text { N-terminal domain } \\ \text { RBD } & \text { Receptor-binding domain } \\ \text { RBM } & \text { Receptor-binding motif } \\ \text { TMPRSS2 } & \text { Type II transmembrane serine proteases } \\ \text { FP } & \text { Furin peptide } \\ \text { HPD } & \text { Heptapeptide domain 1 } \\ \text { TM } & \text { Transmembrane domain } \\ \text { CD } & \text { Cytoplasm domain } \\ \text { hpi } & \text { Hours post-infection } \\ \text { PFU } & \text { Plaque-forming unit } \\ \text { VOI } & \text { Variant of interest } \\ \text { VOC } & \text { Variant of concern } \\ \text { VOHC } & \text { Variant of high consequences } \\ \text { RdRp } & \text { RNA-dependent RNA polymerase }\end{array}$

\section{Introduction}

Coronavirus disease-19 (COVID-19) pandemic will be infamously written in history forever, like Black Death and Spanish flu. Severe acute respiratory syndrome coronavirus-2 (SARS$\mathrm{CoV}-2$ ) is the etiological agent responsible for this pandemic which originated in Wuhan, China, in early December 2019. World Health Organization (WHO) named this disease coronavirus disease-19 (COVID-19) on December 29, 2019. Since the declaration of COVID-19 as a pandemic by the WHO on March 11, 2020 till July 30, 2021, more than 196 million COVID-19 confirmed cases including 4,200,412 deaths were reported, making it one of the deadliest pandemics recorded in human history [1]. SARS-CoV-2 has possibly adapted toward its spread and sustenance for transmission within the community with $\mathrm{R}^{\circ}$ of between 2 and 2.5 .

By 14th July 2021, more the 3.54 billion people have already been vaccinated with at least one dose of the SARS$\mathrm{CoV}-2$ vaccine irrespective of the brand name [2]. Yet, this pandemic has become a race between effective vaccines and the new variants. 


\section{Spike protein and ACE-2 receptor: gateway for viral entry into human cells}

SARS-CoV-2 is an enveloped, single-stranded positive-sense RNA virus with the highest, i.e. $96 \%$ of genome identity with horseshoe bat virus RaTG13 Rhinolophus affinis [3]. The SARS-CoV-2 genome of 30,000 nucleotides includes 5'UTR, followed by ORF1a and ORF1ab, four structural genes (spike $\mathrm{S}$, envelope $\mathrm{E}$, membrane $\mathrm{M}$, nucleocapsid $\mathrm{N}$ ), accessory proteins, and 3' UTR with poly-A tail [4].
The $\mathrm{S}$ gene encodes for the prominent homotrimeric, type I fusion and transmembrane glycoprotein which enables viral entry into the host target cell through the angiotensin-converting enzyme-2 (ACE-2) receptor [5, 6]. 1273 amino acids-long protein is divided into two subunits, i.e. S1 (1-685) and S2 (686-1273). The S1 comprises N-terminal domain (NTD) and receptor-binding domain (RBD; 319-549 a.a.) (Fig. 1).

RBD contains a core structure and a variable receptorbinding motif (RBM; 437-508 a.a.) which interacts and attaches with the host cell ACE-2 receptor (Fig. 2) [7]. The

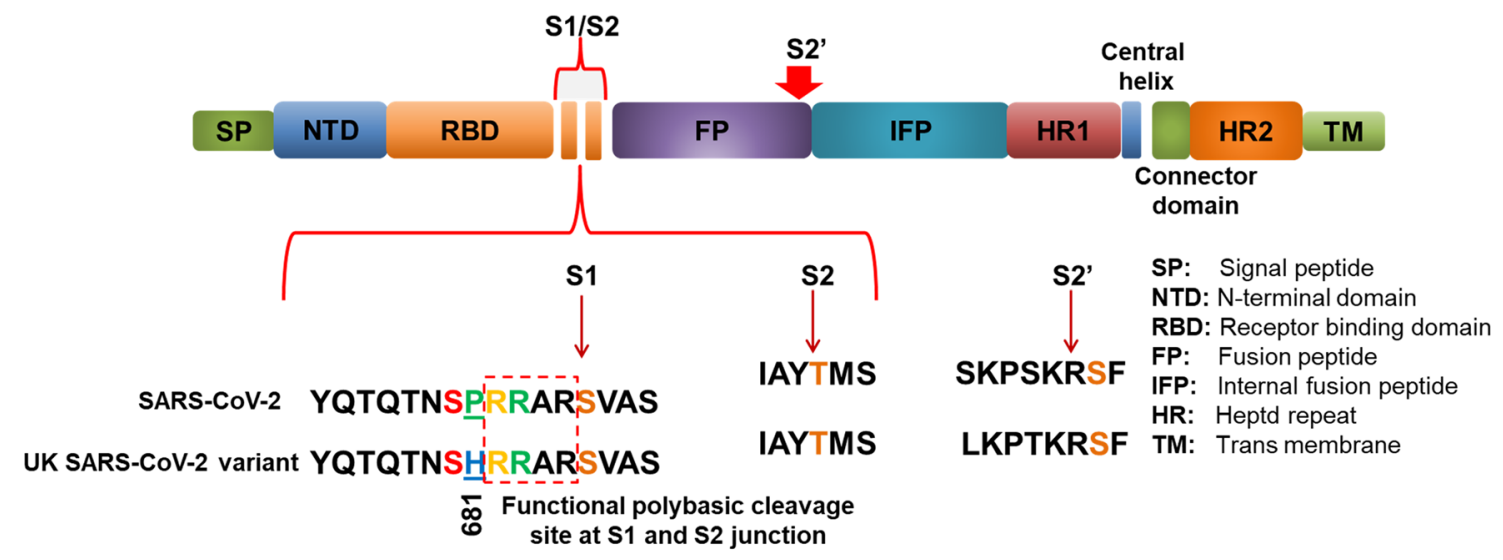

Fig. 1 Diagrammatic representation of spike glycoprotein showing S1 and S2 domain, where S1 contains NTD and RBD and S2 contains FP, IFP, HR1, and HR2. Polybasic cleavage site at the interface of S1/
$\mathrm{S} 2$ contains the RRAR amino acid sequence which is the unique feature of SARS-CoV-2
Fig. 2 Diagrammatic representation of trimeric spike glycoprotein attached with two ACE-2 molecules at receptor-binding site (GVEH) in receptor-binding motif in the $\mathrm{S} 1$ domain

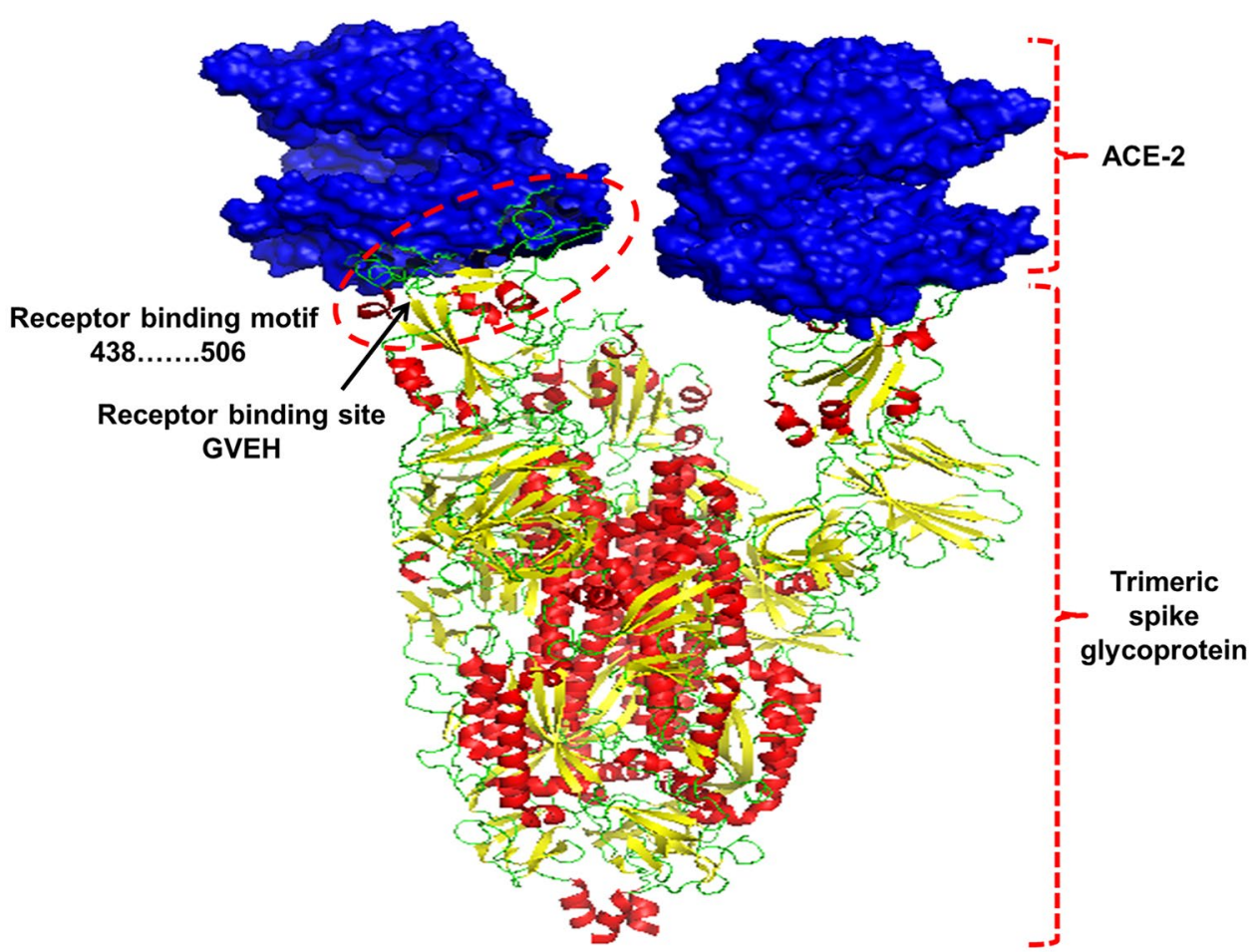


ACE-2 receptors are normally expressed in type II pneumocytes in the alveoli, nasal mucosa, epithelial cells of lungs, kidney, and heart, enterocytes of the small intestine, and endothelial cells of blood vessels, making them vulnerable to SARS-CoV-2 [8]. The widespread presence of ACE-2 receptors in different organs facilitates the extrapulmonary infection by SARS-CoV-2, causing associated complications such as acute respiratory distress syndrome (ARDS), cytokine storm, blood clots [6,9], and possibly psychological and neurological problems [10].

The fusion of two membranes is the crucial step before the virus enters the host cell $[11,12]$. SARS-CoV-2 utilizes ACE-2 as the entry receptor and activates the cellular type II transmembrane serine proteases (TMPRSS2). The priming of spike protein by the host cell is essential for the entry of the virus. This interaction with the ACE- 2 determines the efficiency of SARS-CoV-2 transmissibility [8]. The new variants are found and predicted to exploit a cellular attachment promoting factor to increase the variant's efficiency in terms of both infection and transmission to infect ACE2 cells in the upper respiratory tract [13].

The $\mathrm{S} 2$ subunit is composed of a fusion peptide (FP), heptapeptide domains 1 and 2 (HPD1, HPD2), transmembrane domain (TM), and cytoplasm domain (CD) and is involved in membrane fusion [14]. Non-covalently bound $\mathrm{S} 1$ and $\mathrm{S} 2$ subunits in the pre-fusion state facilitate binding to the host receptor [15]. The spike protein is cleaved by host type II transmembrane serine proteases (TMPRSS2) and furin at the S1/S2 polybasic cleavage site (PRRA) having arginine residues that empower the high cleavability (S2) $[16,17]$. Some studies have indicated the importance of the furin cleavage site for causing conformational changes required for the binding of RBD to the ACE-2 receptor [18].

The S2' cleavage site plays an important role in the activation of membrane fusion and creates an internal fusion peptide within the $\mathrm{S} 2$ domain [19]. In the process of fusion at the S2' site, the type II serine proteases cleave the cell surface, and cysteine-type cathepsin protease is responsible for the intracellular compartment cleavage, which indicates the possibility of the multiple activation triggers set up by the SARS-CoV-2 to infect the cell with critical efficiency [19]. This activity confirms the spike protein to be the deciding factor for the virus infection and transmission. Concerning the immune system, this protein acts as the antigen to activate the appropriate response, which makes it susceptible to further advancement in vaccine development. Being a glycosylated protein, the mutations and the site-specific glycans on infection and immune response play a vital role in anticipating the future of the COVID-19 disease [20].

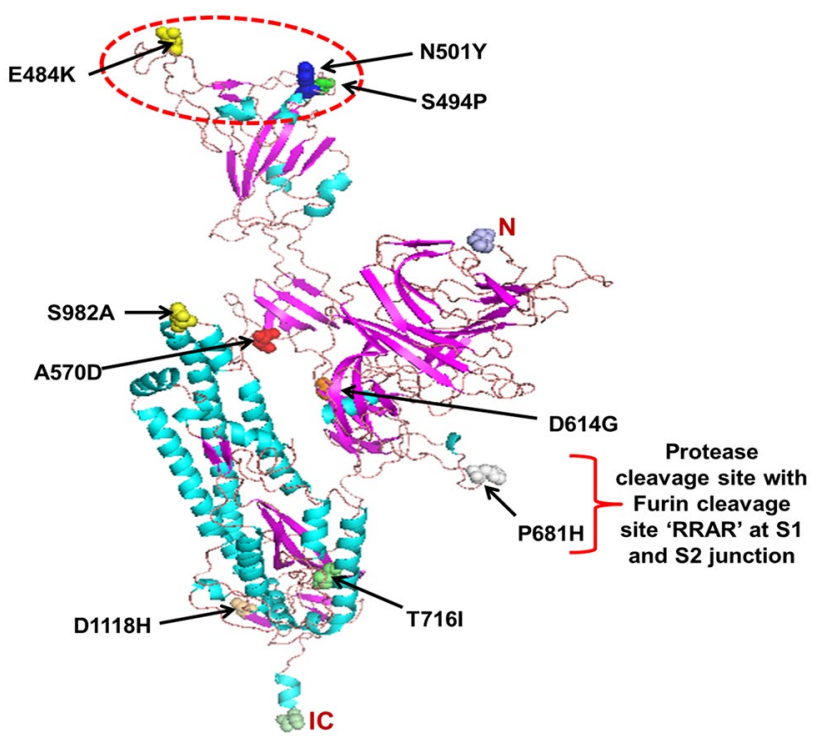

Fig. 3 Structural representation of spike protein showing major mutations in the Alpha (B.1.1.7) variant: N501Y mutation in the receptorbinding motif-containing receptor-binding site is crucial for binding with the hACE-2 receptor. D614G is the dominant substitution possibly responsible for high infectivity. $\mathrm{P} 681 \mathrm{H}$ is important due to its placement next to the furin cleavage site 'RRAR at S1/S2 junction'. Other important mutations in the spike protein are S982A, A570D, $\mathrm{D} 1118 \mathrm{H}$, and T716I

\section{Furin is a masterstroke for SARS-CoV-2 pathogenesis}

Furin is a protease enzyme that cleaves precursor protein at specific sites through proteolysis into a biologically active product. The ubiquitously expressed furin is present in the respiratory basolateral tract, lungs, liver, bone marrow, and salivary glands at a higher concentration which could affect the transmission and stability of the virus. SARS-CoV-2 enters into a human by ACE- 2 receptor and human proteases as entry activators. Preactivation and proteolysis by furin are required for the fusion of viral membranes and host cell membranes. Due to the dissociation of S1 and S2, the virus undergoes a structural change that is irreversible and needs to be tightly regulated. It has been observed that the SARS-CoV-2 arbitrates its virulence after binding to RBD of spike glycoprotein (S1 unit), which mediates interaction with ACE-2 receptors.

The interplay between furin and spike glycoprotein is very fascinating, as furin plays a crucial role in SARSCoV-2 entry and severity in host cells, and therefore reduces the need of other proteases for entry. The focus on the infectivity of SARS-CoV-2 with furin has been solely on the preactivation by furin (proprotein convertase). The protein cleavage site in spike glycoprotein of SARS-CoV-2 in S1/S2 site 1 is arginine (RR) multibasic, i.e. SPRRAR $\$ SVAS at C terminal side (Fig. 3). 
Fig. 4 Diagrammatic representation of D614G variant: change of Asp (GAU) in D614 to Gly (GGU) amino acid results in the D614G mutation as shown in the green spheres in the trimeric spike protein
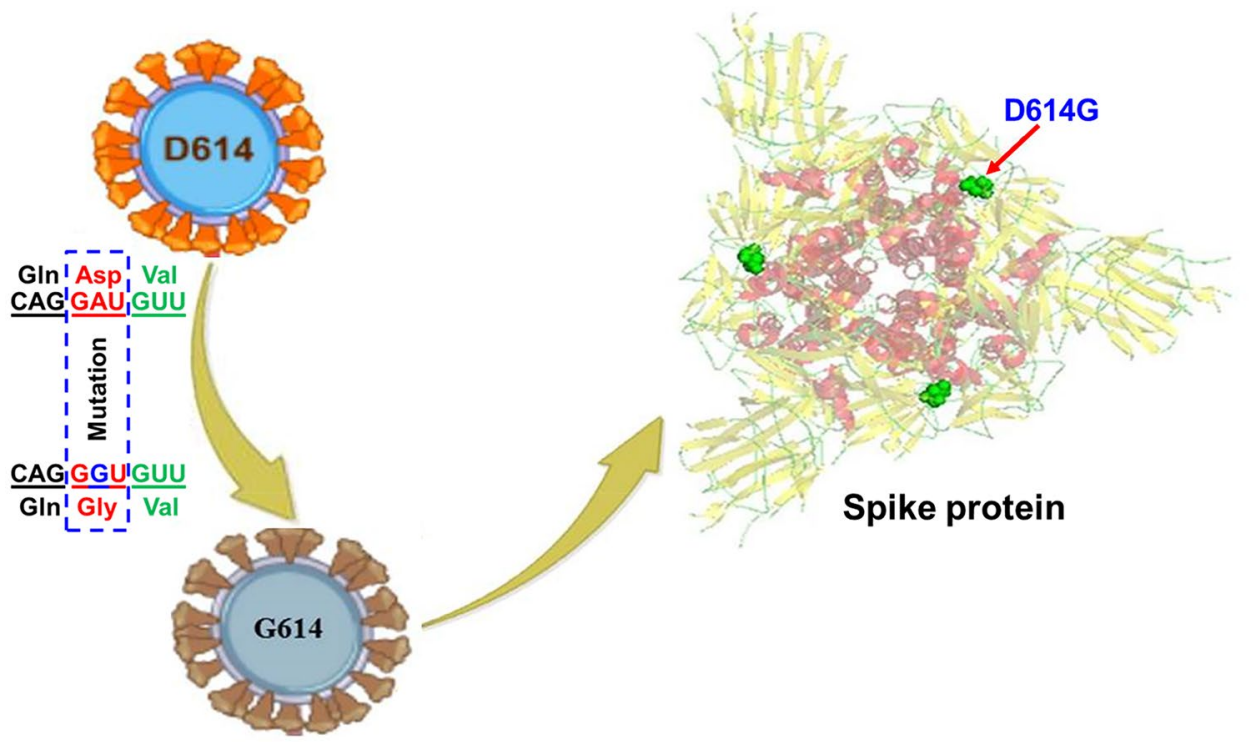

Surprisingly, the SARS-CoV-2 spike protein has a multibasic cleavage site containing arginine residues on the first and fourth position, which efficiently enhance proteolytic cleavage of $\mathrm{S}$ protein with ACE-2 receptor by furin due to the presence of extra arginine at the $\mathrm{P} 4$ position that enhances infection. The lying down (close) state of the spike protein of RBD associated with immune evasion and inefficient hACE-2 receptor binding as recognition motifs are hidden in the closed state. During transition from the close to open (upstate) configuration, RBM is up and receptor-accessible conformation enables the binding to the ACE-2 receptor, which is associated with the strong receptor [21].

The RBD is in direct contact with the ACE-2 where different loops $(1,2$, and 3$)$ and $\beta$-sheets $(1,2)$ are involved in different functions. Based on the "Anchor-Locker" mechanism and binding free energies calculation, loop 2 acts as an "anchor" in recognition and the binding of ACE-2, whereas loop 3 acts as a "locker" to stabilize the whole structure. $\beta$-sheet 1 is involved in enhancing the binding after the recognition process. These interactions reinforce the binding between the spike protein of the SARS-CoV-2 and the ACE-2 of the host cell [22].

\section{SARS-CoV-2 D614G variant: master substitution predominant in the first wave of the pandemic}

Since February 2020 to June 2020, the D614G SARSCoV-2 variant has spread globally with $74 \%$ of the published sequences with aspartic acid to glycine, i.e. D-G substitution in the C-terminal region of the $\mathrm{S} 1$ domain of spike protein [23] (Fig. 4). Zhang et al. [24] reported a more efficient entry of pseudovirus $\mathrm{S}^{\mathrm{G} 614}$ with less $\mathrm{S} 1$ domain shedding in ACE-2 expressing cells. The superior infectivity of the D614G variant is contributed to assembling of more functional $\mathrm{S}$ protein into the virions; however, this mutation neither increases $S$ protein affinity for ACE-2 receptor nor makes pseudoviruses more resistant to neutralization by plasma from convalescent patients. Here, the virus retains the furin cleavage site and therefore may confer a fitness advantage. Studies correlated D614G mutation with higher viral load in nasopharyngeal aspirate, supporting the advantage in transmission, fitness advantage, and enhanced infectivity in COVID19 patients [25]. Jessica A et al. [26] studied replication kinetics of the D614G variant in human lung epithelial cell line Calu-3 and found 2.4-fold more infectious virus $36 \mathrm{hpi}$, indicating enhanced viral replication. Competition assay studies on the fitness of D614G virus, by infecting hamsters intranasally with $10^{4} \mathrm{PFU}$ per virus, showed G614/D614 ratios of 1.2-2.6, indicating fitness advantage of the D614G variant. D614G is the only substitution mutation that is present in all the five VOI and four VOC which are circulated in the populations throughout the world. The first wave predominantly infected older and immunocompromised populations and people with underlying complications.

\section{Possible mechanism of high transmissibility and infectivity}

Structural analysis by atomic simulations and molecularlevel studies showed asymmetric inter-promoter interactions between $\mathrm{S} 1$ and $\mathrm{S} 2$ subunits in the open state during the D614 form. However, in the G614 form, due to the 
relaxation of tensile hydrogen bonds, a higher population of infection capable of open configurations results in higher chances of binding events with the host receptor ACE-2, thereby increasing the overall infectivity. Enhanced exposure of RBD in the open configuration is also predicted to be a reason for higher sensitivity toward neutralization [27].

The other possible reasons for the high mortality during the first wave were the lack of understanding of virus structure, its pathogenesis, transmission dynamics, absence of vaccines and antivirals. In addition to this, other reasons were infected hosts' dysregulated hyperinflammatory response, the immunocompromised status of individuals, multi-organ tropism, and mutations in the virus, which cumulatively worsened the first phase of the pandemic. With the unavailability of vaccines, short supply of the available drug, limited laboratory testing, lack of scientific understanding of the virus, untrained healthcare staff, and absence of proper treatment to a large population at a reasonable cost during the first wave of COVID-19 resulted in a critically much higher death rate [28].

Generally, numerous other factors responsible for the increase in the number of cases and mortality throughout the world are economic inequality, per capita hospital beds, and blood types, with Group $\mathrm{B}$ and $\mathrm{AB}$ being protective against COVID-19. Changes in lifestyle, i.e. high intake of oil, vitamin D, and vitamin K reduces the COVID-19 risk, while increased intake of alcohol and smoking are associated with increased COVID-19 risk [29]. Such factors affect COVID-19 transmission and severity, and by modulating these, effective strategies can be formulated to prevent and mitigate COVID-19 spread.

\section{Emergence and classification of new SARS-CoV-2 variants}

SARS-related coronaviruses appear frequently in bats (proximal source) [30]. Zoonotic transmission of such viruses is inevitable due to human activities involving close contact with wild mammals harboring these viruses. Being an RNA virus in nature, SARS-CoV-2 is susceptible to a high rate of mutations, leading to the evolution of various variants in a shorter period than anticipated. The reason for the great genetic diversity of SARS-CoV-2 is the strand-switching ability and error-prone activity of RdRp. Events of frequent recombination of different coronaviruses strains lead to diversification and eventually evolution of a potent humaninfecting SARS-CoV-2 strain [31]. For the SARS-CoV-2 genome, the nonsynonymous to synonymous substitutions ratio is 0.028 , indicating strong purifying selection [32].

Although $3^{\prime}-5^{\prime}$ exonuclease proofreading activity slows the mutation rate, accumulating amino acid mutations alters the cell tropism, transmissibility, and pathogenicity of SARS-CoV-2 [33]. The mutations in the spike protein such as deletions, substitutions, and recombinations mainly in RBD can virtually create a highly lethal variant to a highly transmissible one, possibly due to the alteration in ACE-2 binding affinity [34]. Various mutations in the new variants are mentioned in Table 1. The World Health Organization (WHO) classifies SARS-CoV-2 variants as variants of interest (VOI), variants of concern (VOC), and variant of high consequences (VOHC).

Table 1 SARS-CoV-2 variants showing prominent mutations in the RBD and spike protein

\begin{tabular}{lllll}
\hline Variant name & Name by WHO & Country of origin & \multicolumn{2}{l}{ Mutations } \\
\cline { 3 - 4 } & & & in RBD & in S-glycoprotein \\
\hline B.1.1.7 & Alpha & UK (November, 2020) & E484K, S494P, N501Y & $\begin{array}{c}\text { 69/70del, 144del, A570D, D614G, P681H, } \\
\text { T716I, S982A, D1118H, K1191N }\end{array}$ \\
B.1.351 & Beta & South Africa (October, 2020) & K417N, E484K, N501Y & D80A, D215G, 241/243del, D614G, A701V \\
P.1 & Gamma & Japan/Brazil (December, 2020) & K417T, E484K, N501Y & L18F, T20N, P26S, D138Y, R190S, D614G, \\
& & & & H655Y, T1027I \\
B.1.614.2 & Delta & India (December, 2020) & L452R, T478K & T19R, G142D, D614G, P681R, R158G, \\
& & & & 156/157del, D950N \\
B.1.427 & Epsilon & USA (July, 2020) & L452R & D614G \\
B.1.429 & Epsilon & USA (July, 2020) & L452R & F565L, D614G, V1176F \\
P.2 & Zeta & Brazil (April, 2020) & E484K & A67V, 69/70del, 144del, D614G, Q677H, F888L \\
B1.525 & Eta & USA (December, 2020) & E484K & 141/143del, D614G, P681H, E1092K, H1101Y, \\
P.3 & Theta & Japan/Philippines (February, 2021) & E484K, N50 & V1176F \\
B.1.617.1 & Kappa & India (December, 2020) & E484Q, L452R & T95I, D614G, E154K, P681R, G142D, Q1071H \\
C.37 & Lambda & Peru (November 2020) & L452Q, F490S & G75V, T76I, D614G, T859
\end{tabular}




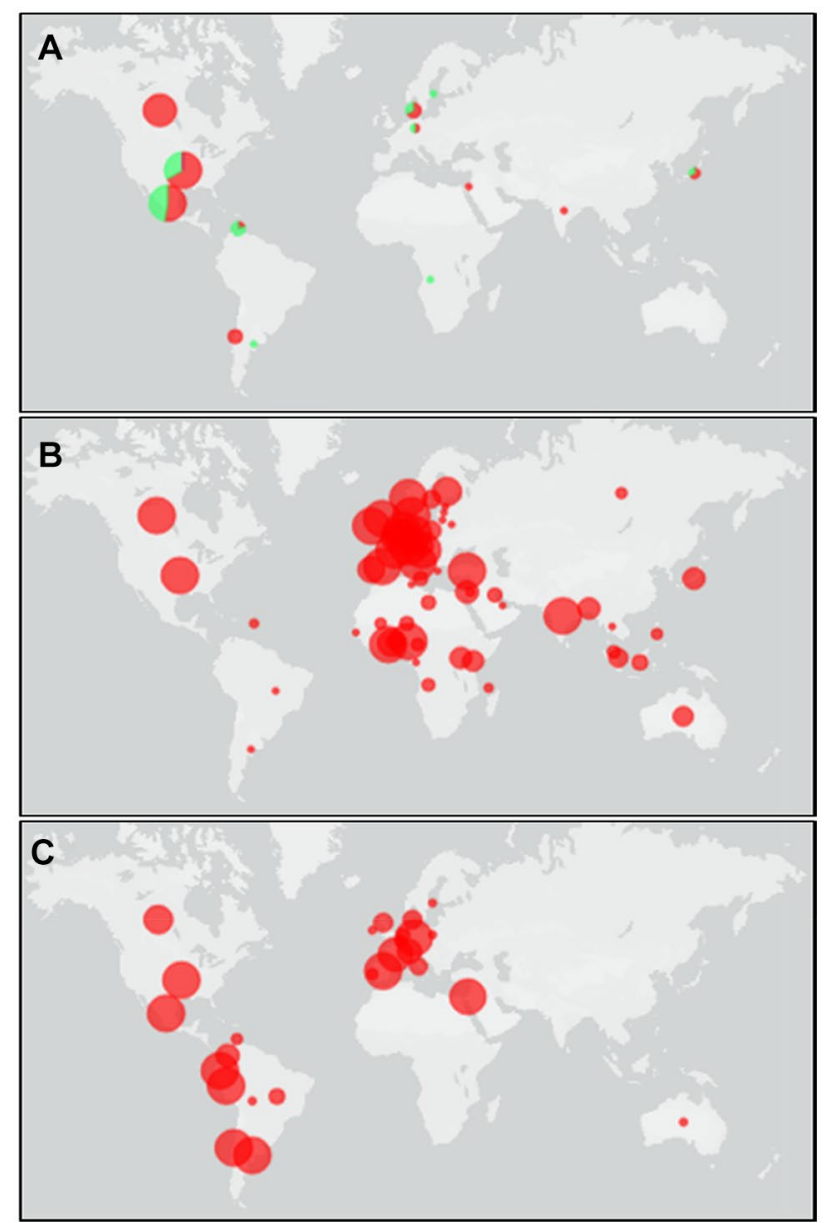

Fig. 5 Pictorial presentation showing geographical distribution and phylodynamics of SARS-CoV-2 variants of interest (VOI): Epsilon variant red square B.1.429, pink square B.1.429.1 and green square B.1.427 (A); Eta variant red square B.1.525 (B); Lambda variant red square C.37 (C) [37]

\section{Variants of interest (VOI)}

SARS-CoV-2 variants have specific genetic markers that have been predicted to affect virus transmission, reduce therapeutics efficiency and neutralization capacity by antibodies or immune evasion, and increase disease severity [35]. Epsilon, Eta, Iota, Kappa, Zeta, and Lambda are the variants of interest circulating throughout the world.

\section{Epsilon (GH/452R.V1)}

The Epsilon (GH/452R.V1) variant first identified in California, the USA in 2021, showed a $20 \%$ increase in transmission possibly attributed to the L452R and D614G substitutions in the spike protein [36]. As of 13th July 2021, cases of Epsilon variant have been reported from 34 nations dominantly in the USA $(52,967)$, Mexico (477), Canada (331), South Korea (109), Aruba (58), Denmark
(36), Chile (30), Argentina (28), UK (22), Australia (20), and Colombia (20) (Fig. 5 A) [37]. Epsilon was identified as two separate lineages, i.e. B.1.427 with two spike mutations (L452R, D614G) and B.1.429 lineage consisting of four mutations (S13I, W152C, L452R, and D614G) [35]. The most concerning L452R mutation in RBD is common to both the lineages and indirectly alters the structure, promoting and stabilizing the interaction between the spike protein and ACE-2 receptor. This variant showed reduced resistance to neutralization by convalescent (4-6.7-fold) and post-vaccination sera (2-2.9-fold) against this variant $[38,39]$.

A novel mechanism of immune evasion was studied in the Epsilon variant, where the other two mutations remodeled NTD by shifting the signal peptide cleavage site in the NTD antigenic supersite and forming a new disulfide bond. This signal peptide modification resulted in a total loss of neutralization by ten NTD-specific antibodies [40].

\section{Eta (G/484 K.V3; B.1.525)}

The Eta (G/484 K.V3; B.1.525) variant was first identified in December 2020 from the UK and Nigeria and labeled as VOI in March 2021 [41]. In addition to the UK and Nigeria, Eta cases have been reported from 70 other countries such as Canada (1417), USA (1210), Germany (745), France (702), Denmark (613), UK (520), Italy (406), Nigeria (267), India (234), and Spain (190) (Fig. 5B) [37]. This variant has substitutions in the spike glycoprotein at A67V, E484K, D614G, $\mathrm{Q} 677 \mathrm{H}$, and F888L with three deletions at $69 \mathrm{Hdel}, 70 \mathrm{Vdel}$, and 144del [42]. The major concern is the E484K mutation in the RBD, which is also seen in the VOCs such as Alpha, Beta, and Gamma helping in evading the antibodies. This variant showed reduced neutralization by bamlanivimab and etesevimab monoclonal antibodies and convalescent sera $[43,44]$.

\section{lota (GH/253G.V1; B.1.526)}

The Iota (GH/253G.V1; B.1.526) variant with its sublineage B.1.526.1 was first identified in New York in November 2020, now spreading to more than 60 countries, predominantly in the USA, Ecuador, Canada, Spain, Columbia, Aruba, Mexico, Germany, and the UK. Worldwide, it accounts for $2 \%$ of the coronavirus sequences. L5F, T95I, D253G, (L452R*), E484K, D614G, and A701V are important spike protein substitutions that may impart reduced susceptibility to MAb's treatments along with reduced neutralization capacity by post-vaccination sera [45]. Research suggested that mRNA vaccines (Moderna and Pfizer) are protective against Iota variants [46]. 


\section{Kappa (G/452R.V3; B.1.617.1)}

The Kappa (G/452R.V3; B.1.617.1) variant was first identified in Maharashtra, India, in December 2020, and now has been detected in at least 52 countries with dominance in India (4,235), UK (518), USA (304), Canada (267), Ireland (178), Australia (128), Germany (106), Singapore (59), Netherlands (28), and Denmark (28)[37]. This variant has substitutions in the spike protein at T95I, G142D, E154K, D614G, P681R, Q1071H, and L452R, E484Q in its RBD region, which may provide this variant reduced resistance to neutralization by post-vaccination sera [47]. It has been reported that the neutralization antibody titer of the Covishield' (AstraZeneca and Serum Institute of India) vaccinated individuals provide protection from the Kappa variant after the second dose of vaccination [48].

\section{Zeta (P.2)}

The Zeta (P.2) variant was identified in Brazil in April 2020 with important substitutions at E484K, F565L, D614G, and V1176F in the spike protein [42].

\section{Theta (P.3, B.1.1.28.3)}

Theta (P.3, B.1.1.28.3) was reported in Japan and the Philippines in February 2021. The major mutations found in the spike glycoprotein of this variant are 141/143del, D614G, P681H, E1092K, H1101Y, and V1176F, and in the RBD region E484K and N501 [42]. As of 13th July 2021, 209 (Philippines), 16 (USA), 11 (Germany), 10 (Malaysia), 9 (China), 7 (UK), 7 (Netherlands), 5 (Japan), 4 (Australia), and 3 (Belgium) cases of Theta variant have been reported [37].

\section{Lambda (GR/452Q.v1)}

The Lambda (GR/452Q.V1) variant originated in Peru in August 2020 [49]. Previously known as C.37 or Andean variant, this could be a new emerging threat; therefore, WHO on June 14, 2021 declared this as a VOI [50]. The variant has seven significant mutations, i.e. G75V, T76I, del247/253, L452Q, F490S, D614G, and T859N in the spike protein. The L452Q and F490S mutations reported in the RBD region have been shown to increase the viral infectivity, rendering the virus more infectious and able to escape immune response from specific monoclonal antibodies [51,52] or disrupt the ability of vaccine-generated antibodies to recognize the variant [53]. F490S mutation helps the Lambda variant to escape convalescent sera and neutralizing antibodies from the CoronaVac vaccine and also reduced in vitro susceptibility to neutralization [54]. The 247/253del in the NTD is located in the antigenic supersite, giving the Lambda variant advantage of further immune escape. D614G is again associated with the increase in transmissibility, infectivity, and viral load, making the Lambda variant even more lethal [55]. The Lambda variant accounts for $82 \%$ of the infections in Peru and $31 \%$ in Chile, whereas so far only eight cases (overseas travel) have been reported from the UK. As of 13th July 2021, more than 30 countries have reported cases of Lambda variants such as Chile $(1,022)$, USA (703), Peru (571), Mexico (125), Germany (100), Argentina (87), Ecuador (68), Spain (56), Israel (25), and Colombia (20) (Fig. 5C) [37]. This is suspected to be more transmissible than the original virus and is a matter of great concern, as this has been detected in the UK and other European countries. Studies have shown the greater infectivity of Lambda variants in comparison to Alpha and Gamma variants of the VOC category. Decreased effectiveness of Sinovac vaccine (Coronavac) against the Lambda variant, in addition to significant community transmission, is a matter of great concern [56]. The Lambda variant spike protein is found to be 3.3 times more resistant to neutralization by the convalescent sera than the parent D614G spike protein and 4.9 times to that of the Alpha variant ones. The monoclonal antibody (REGN10987) in the Regeneron REGN-COV2 therapy is reported to be ineffective, i.e. the Lambda variant is found to be 3.6 times more resistant to neutralization by REGN10987 [57].

In Asia, so far only Israel has reported the Lambda variant, which can be introduced to other Asian countries due to relaxation in international travel to and from the European countries. These variants have the potential to bypass the vaccination-induced immunity, which could become the reason for the third wave of COVID infection.

\section{Variants of concern (VOC): possible reasons for the second wave}

Variants of concern showed evidence of an increase in transmissibility, disease severity, and a significant reduction in neutralization by antibodies generated during previous infection or vaccination [58]. There are four variants of concern, i.e. Alpha, Beta, Gamma, and Delta variants distributed throughout the globe and responsible for a second and third wave of the pandemic.

\section{Alpha (B.1.1.7; 20I/501Y.V1)}

The Alpha variant was first identified in the UK in November 2020 from a 58-year-old male [59]. This Alpha variant increased its severity (40-80\%) through the air pathway and the associated case fatality is expected to be $55 \%$ higher with a higher death rate $[60,61]$. A total of 23 mutations are present in this variant, of which 14 are nonsynonymous, 3 are deletions, and 6 are synonymous mutations such as H69del, 


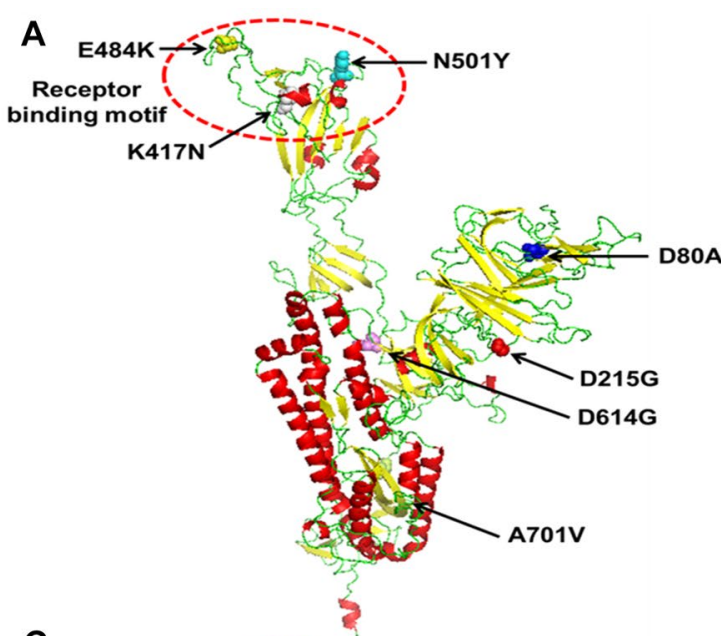

C

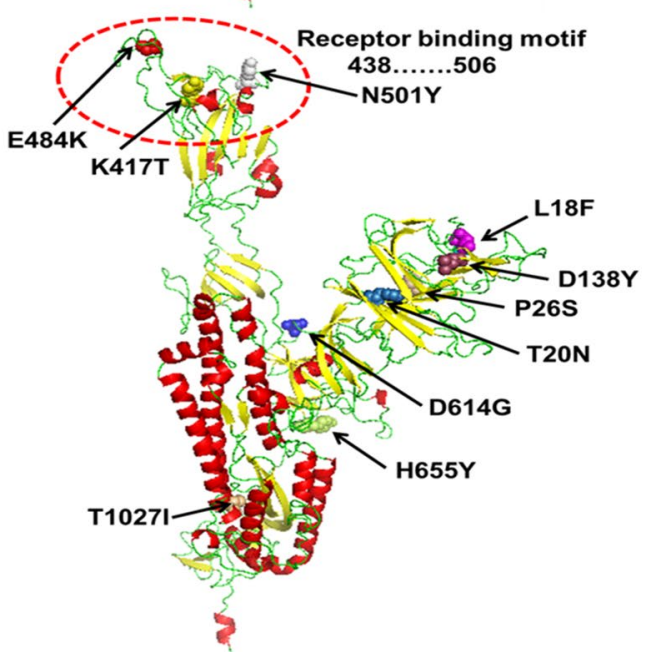

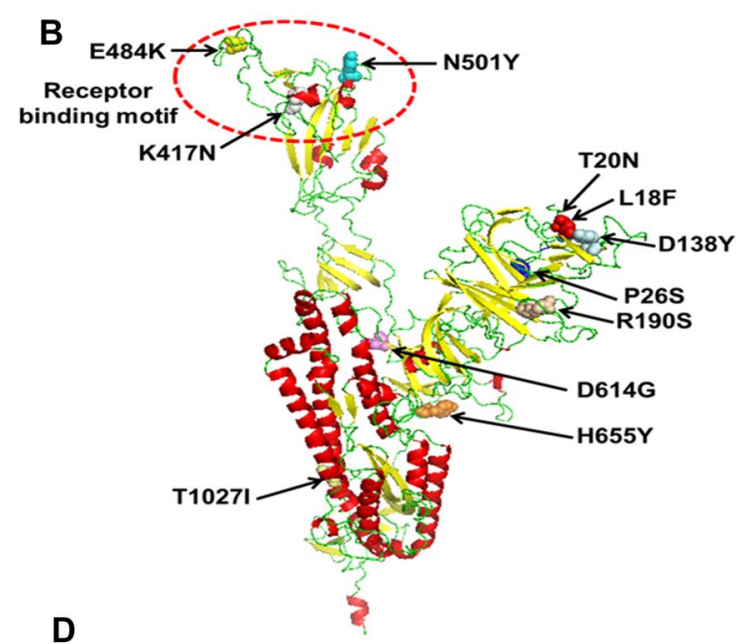

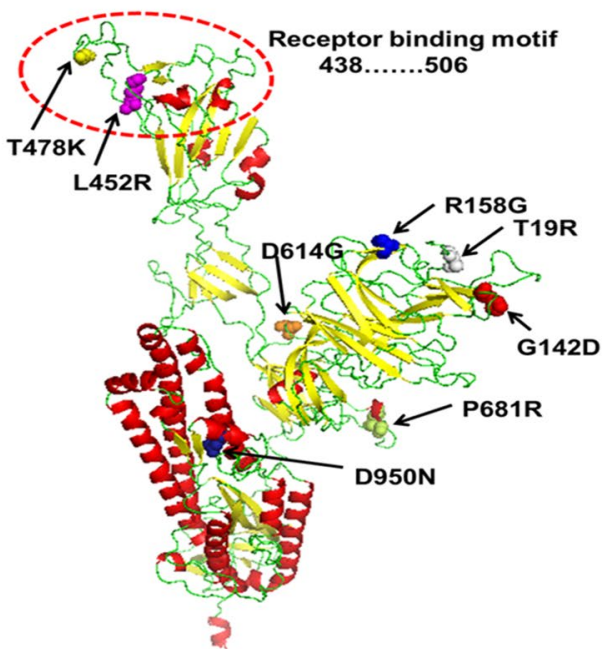

(a-c). T478K and L452R mutations in RBM of Delta variants (d). Other mutations are highlighted with different color codes

(266,186), USA (201,074), Germany (101,697), Denmark $(59,844)$, Sweden $(56,325)$, France $(32,208)$, Netherlands $(27,660)$, Italy $(24,075)$, Japan $(22,382)$, and Switzerland $(21,628)$ (Fig. 7A), suggesting community transmission and hospitalization [37].

\section{Beta (B.1.351; GH/501Y.V2)}

The Beta (B.1.351; GH/501Y.V2) variant was identified in Cape province of South Africa in October 2020 with 17 critical mutations, showing a $50 \%$ increase in transmission [67]. It contains three deletions (241del, 242del, 243del) in the N5 loop and seven substitutions (D80A, D215G, K417N, E484K, N501Y, D614G, A701V) in the spike protein (Fig. 6B) [42]. K417N, E484K, and N501Y mutations in the RBD are of the greatest concern, as the virus can escape the neutralizing monoclonal antibodies, with a chance of better survival. N501Y mutation allows tries reported the presence of Alpha variant cases, i.e. UK 
Fig. 7 Pictorial presentation showing geographical distribution and phylodynamics of SARS-CoV-2 variants of concern (VOC): Alpha variant red square B.1.1.7; pink square B.1.274 (A); Beta variant red square B.1.35 (B); Gamma variant red square P.1 (C); Delta variant red square B.1.617.2, pink square AY.1, green square AY.2 (D) [37]
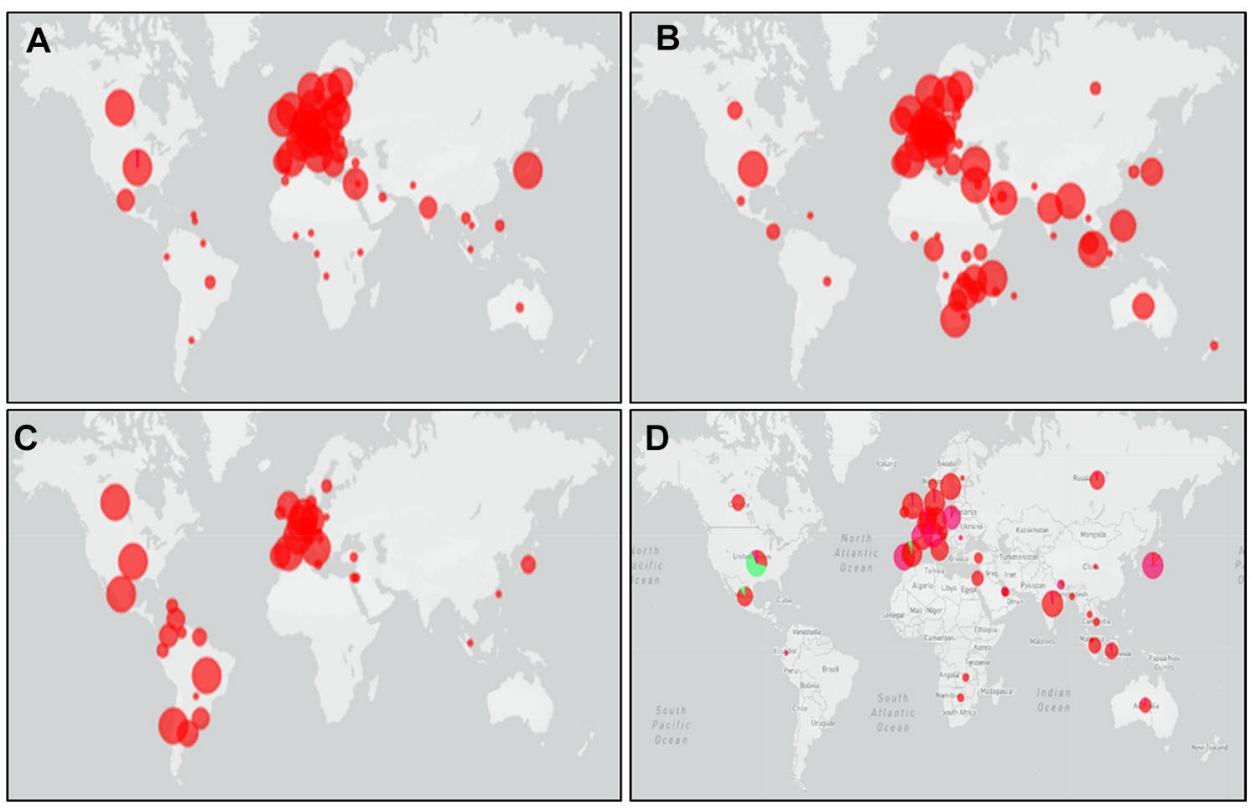

a higher binding affinity (4.62 times more in comparison to the original SARS-CoV-2) for the ACE2 receptor [68], whereas $\mathrm{K} 417 \mathrm{~N}$ and $\mathrm{E} 484 \mathrm{~K}$ may change the shape of spike protein making them escape from neutralizing antibodies [69]. As of 13th July 2021, cases of Beta variant have been reported from 113 countries, mainly from South Africa (6164), USA (2327), Sweden (2317), Germany (2200), France (2111), Philippines (1216), Finland (1096), Belgium (1069), Canada (854), UK (809) and Colombia (20) (Fig. 7B) [30, 70].

\section{Gamma (P.1;GR/501Y.V3)}

The Gamma was identified for the first time in November 2020 in Manus, Brazil (B.1.1.248.1) and labeled as a VOC on Jan 11, 2021 [41]. 11 crucial mutations in the spike protein, with 5 mutations within NTD (L18F, T20N, P26S, D138Y, R190S), 3 in RBD (K417T, E484K, N501Y), 2 in the C-terminal domain of $\mathrm{S} 1$ and near the furin cleavage site (D614G, H655Y), and 1 in S2 (T1027I) are reported (Fig. 6C) [71]. K417T mutation may help the Gamma variant to latch onto cells. Faria et al. [72] suggested twofold transmissibility and higher viral load with Gamma variants. The Gamma variant was found to be responsible for the re-infection in São Paulo State and caused the second wave in Brazil [42]. As of 13th July 2021, cases of Gamma variant have been reported in 74 countries such as the USA (19,953), Brazil (13,598), Canada (7,571), Belgium (1735), Chile (1718), Mexico (1480), Spain (860), Italy (627), Netherlands (521), and Germany (339) (Fig. 7C) $[37,73]$.

\section{Delta (G/478 K.V1; B.1.617.2)}

The Delta (G/478 K.V1; B.1.617.2) variant, first identified in Maharashtra, India, in October 2020, is now found to be the dominant lineage detected in more than 100 nations and declared as VOC by the WHO on May 11, 2021 [74]. Delta strain drives the second wave in India, where almost 4-lakh cases were reported per day. The Delta variant is responsible for the third wave in the UK, where it seems to be around $60 \%$ more transmissible than the Alpha variant [75]. The increased growth rate of the Delta variant was confirmed by interpreting the spike gene target data, where $\mathrm{S}$ gene target in a three-target assay of S, N, and ORF1ab was detected in Kappa and Delta variants [76]. 13 mutations are present in spike protein, i.e. T19R, G142D, 156del, 157del, R158G, L452R, T478K, D614G, P681R, D950R, P871R, T95I, A222V*, and K417N* (Fig. 6D) [77]. The T478K mutation is found to be more adapted and influences the virus affinity to the human cells, leading toward increased viral infectivity [78]. The 156/157 deletions alter the 158th amino acid from arginine to glycine, which eventually removes a direct contact point for the antibody binding on the variant [79]. The P681R mutation changes an amino acid at a spot directly beside the furin cleavage site, making the furin cleavage much more efficient and easier for the variant $[75,79]$. This change gives the variant immunity against the specific antibody and further influences the survival of the Delta variant.

Another crucial mutation L452R in the RBD facilitates higher transmission efficiency into the cells, so that the variant can spread quickly from one person to another. It is anticipated that this mutation facilitates $18-24 \%$ higher 
transmissibility and 20 times reduction in the neutralizing titers from the vaccinated individual [38], and is also resistant to neutralization by specific antibodies [42].

Usually, vaccines work against the Delta variant; however, in a recent study, COVID-19 vaccines were found to be less effective against the Delta variant in people who received only one dose. The Pfizer-BioNTech and OxfordAstraZeneca were $88 \%$ and $60 \%$ effective against the SARSCoV-2 Delta variant, 2 weeks after the second dose. However, both these vaccines are only $33 \%$ effective against the Delta variant 3 weeks after the first dose. Pfizer-BioNTech and Moderna vaccines showed decreased neutralization [80].

\section{Delta Plus: possible reason for the third wave}

Delta Plus variants known as AY.1 (B.1.617.2.1) and AY.2 (B.1.617.2.2) have now become a new cause of global concern. The Indian government declared AY.1 (B.1.617.2.1) as a VOC. In addition to three mutations, E484Q, L452R, and P614R, these new sub-lineages have additional K417N mutations in the spike proteins that enhance virus attachment to the infected cells and have immune evasion properties as in the Beta variant (B.1.351 lineage). So far, India has reported 56 cases of Delta Plus variants (AY.2) in Andhra Pradesh, Karnataka, and Maharashtra, and AY.1 variant in Maharashtra, Punjab, Telangana, Rajasthan, Gujarat, and Karnataka. Globally, AY.2 has been reported from Turkey, the USA, Portugal, and India. The Delta Plus variant has increased transmissibility, causes stronger binding to receptors of lung cells, and has the potential of reducing monoclonal antibody response. Though this variant has a greater affinity to the mucosal lining in the lungs, the severity of damage is yet to be elucidated.

P871R mutation is one of the most critical mutations in Delta Plus, i.e. in the furin binding site, which enhances the efficiency of getting into the cell through the furin cleavage site itself. It produces syncytia, so that virus infects multiple cells by the cell-to-cell transfer mechanism without getting out of the cell. In such a situation, even monoclonal antibodies are not effective and are likely to lose some amount of efficiency in the Delta variant.

Considering the fact that a large population gets infected in the second wave and most of the population becomes vaccinated, there may be chances that people may not develop a serious and fatal illness with Delta Plus variant.

The secondary attack rates for contacts of cases with Delta and no travel history are of higher value of about $12.4 \%$ than that of the Alpha of about 8.2\% [76]. As of 13th July 2021, cases of Delta variant have rose up to 131,748 (UK), 14,643 (USA), 12,118 (India), 2688 (Germany), 2,555 (Denmark), 2115 (Canada), 1992 (Portugal),
1,727 (Sweden), 15,777 (Spain), and 1549 (Italy) (Fig. 7D) [37].

\section{The variant of high consequence}

A variant with clear evidence demonstrating the failure of diagnostics reduces vaccine effectiveness and reduced susceptibility to approved therapeutics causing severe clinical disease. So far, the absence of a variant of high consequences is a major sign of relief to the world [58].

\section{Vaccines and their effectiveness against variants}

Pfizer-BioNTech and Moderna mRNA COVID-19 vaccines are effective in symptomatic Alpha variant infections. Sera from the Pfizer-vaccinated health-care worker is found to be effective in neutralizing B.1.1.7 [81]. Johnson and Johnson vaccine single shot is quite effective in stimulating protective neutralizing antibodies [82]. Moderna and Novavax vaccines showed decreased neutralization. Pfizer-BioNTech and Moderna vaccines showed no change in $\mathrm{S} 447 \mathrm{~N}$, but decreased neutralization on E484K [83].

The majority of the vaccines have lower efficacy against Beta strains. Pfizer vaccine showed only $75 \%$ efficacy [84], whereas AstraZeneca AZD1222 vaccine failed in preventing even mild and moderate COVID-19 infection in South African trials [85, 86]. NVX-CoV2373 (Covavax) and Covaxin vaccine showed good neutralization. Pfizer-BioNTech and Moderna vaccines showed decreased neutralization. BNT162b/2 and mRNA-1273 mRNA-based vaccines showed decreased neutralization in Gamma variants. Convalescent plasma and antibodies from vaccinated people are less effective in neutralizing the Gamma variant [87].

\section{Immune evasion in SARS-CoV-2 variants}

SARS-CoV-2 has a slow evolutionary rate, yet during pandemic rapid transmission enabled it to acquire significant genetic diversity, resulting in the emergence of variants that can impact transmission and infectivity. The possible theories about the origin of novel variants are the evolution of circulating intermediate mutants in the chronically infected immunocompromised patients supporting high viral replication while on treatment with immune plasma or monoclonal antibodies [88, 89]. In such immunocompromised patients, a high accumulation of immune complexes escapes mutants, and develop immune evasion facilitating the emergence of highly infective variants [90]. Adaptive evolution in the virus may be responsible for cross-species transmission 
as reported in mink-associated SARS-CoV-2 infection in humans [91].

The existing vaccines are ineffective against the new variants, and the reason is no other mutations are involved in immune escape. To understand more clearly, the concept of immune response is related to the affinity between antibodies and the variants [42]. Mutations in the RBD region are likely to disrupt antibody recognition [53]. The cross-reactivity between the variants and the elicited neutralizing antibodies is the critical factor where high cross-reactivity results in higher chances of neutralizing a virus; otherwise, the variant can easily escape the immune system [92]. The various mutations in the RBD region of different variants are found to have a direct impact on the immune escape against the various vaccines under use for treatment [39]. In the Alpha variant, due to the $\mathrm{E} 484 \mathrm{~K}$ mutation, the immune sera from the human vaccinated with Pfizer/BioNTech is significantly reduced in neutralizing titers [93]. The ChAdOx1 vaccine from AstraZeneca, which showed $75 \%$ protection against the Alpha variant, was only able to show $10 \%$ protection against the Beta variant $[94,95]$. There is no doubt that new variants evolved to have the characteristics of the immune escape, which may likely create the requirement to replace the current vaccines quickly. A large amount of diversified research is required to deal with the immune escape problem.

An ongoing evolution of the SARS-CoV-2 creates different VOCs such as Alpha, Beta, Gamma, and Delta, of which the Delta variant possibly is the causative agent of

Table 2 Authorized and approved vaccines of COVID-19 treatment [104, 105]

\begin{tabular}{|c|c|c|c|c|c|c|}
\hline Vaccine & Manufacturer & Platform & Country & Doses & Efficacy (\%) & Storage \\
\hline BNT162b/2 & Pfizer-BioNTech & $\begin{array}{l}\text { Nucleoside-modi- } \\
\text { fied mRNA-based } \\
\text { vaccine }\end{array}$ & USA & $\begin{array}{l}2 \text { doses } 3 \text { weeks } \\
\text { apart }\end{array}$ & 91.3 & $\begin{array}{l}-80 \text { to }-60{ }^{\circ} \mathrm{C} \\
\quad(6 \text { months }) \\
2-8{ }^{\circ} \mathrm{C} \text { (5 days) }\end{array}$ \\
\hline mRNA-1273 & Moderna & $\begin{array}{l}\text { mRNA-based vac- } \\
\text { cine encapsulated } \\
\text { in lipid nanoparti- } \\
\text { cle (LNP) }\end{array}$ & USA & $\begin{array}{l}2 \text { Doses } 4 \text { weeks } \\
\text { apart }\end{array}$ & 94.5 & $\begin{array}{l}-25^{\circ} \mathrm{C} \text { to }-15^{\circ} \mathrm{C} \\
(6 \text { months }) \\
2-8{ }^{\circ} \mathrm{C}(30 \text { days })\end{array}$ \\
\hline $\begin{array}{l}\text { AZD1222 } \\
\text { Covishield }\end{array}$ & AstraZeneca-Oxford & $\begin{array}{l}\text { Recombinant } \\
\text { ChAdOx1 } \\
\text { adenovirus vector } \\
\text { encoding spike } \\
\text { protein Ag of the } \\
\text { SARS-CoV-2 }\end{array}$ & UK, USA & $\begin{array}{l}2 \text { doses between } \\
4 \text { and } 12 \text { weeks } \\
\text { apart }\end{array}$ & 90.0 & $2-8^{\circ} \mathrm{C}$ (6 months) \\
\hline $\begin{array}{l}\text { Sputnik V } \\
\text { rAd26 } \\
\text { rAd5 }\end{array}$ & $\begin{array}{l}\text { Gamaleya Research } \\
\text { Institute }\end{array}$ & $\begin{array}{l}\text { Recombinant } \\
\text { adenovirus vector- } \\
\text { based COVID-19 } \\
\text { vaccine }\end{array}$ & Russia & $\begin{array}{c}2 \text { different doses } \\
3 \text { weeks apart }\end{array}$ & 92.0 & $\begin{array}{l}2-8{ }^{\circ} \mathrm{C} \text { (dry form) } \\
-18^{\circ} \mathrm{C} \text { (liquid form) }\end{array}$ \\
\hline $\begin{array}{l}\text { Ad26.CoV.S } \\
\text { JNJ-78436735 }\end{array}$ & $\begin{array}{l}\text { Johnson \& Johnson, } \\
\text { Janssen vaccines }\end{array}$ & $\begin{array}{l}\text { Recombinant, } \\
\text { non-replicating } \\
\text { adenovirus type } 26 \\
\text { vectored vaccine } \\
\text { encoding SARS- } \\
\text { CoV-2 spike } \\
\text { protein }\end{array}$ & Netherland, USA & Single dose & 72.0 & $2-8^{\circ} \mathrm{C}$ (3 months) \\
\hline $\begin{array}{l}\text { COVAXIN } \\
\text { BBVI52 }\end{array}$ & Bharat Biotech & $\begin{array}{l}\text { The whole SARS- } \\
\text { CoV-2 virus } \\
\text { inactivated (Vero } \\
\text { cell) }\end{array}$ & India & $\begin{array}{l}2 \text { doses } 4 \text { weeks } \\
\text { apart }\end{array}$ & 81.0 & $2-8{ }^{\circ} \mathrm{C}$ \\
\hline Corona Vac & Sinovac & $\begin{array}{l}\text { Inactivated vaccine } \\
\text { (Vero cell, forma- } \\
\text { lin with alum) }\end{array}$ & China & 2 doses & $50.0-84.0$ & $2-8{ }^{\circ} \mathrm{C}$ \\
\hline $\begin{array}{l}\text { NVX-CoV2373 } \\
\text { Covavax }\end{array}$ & NovaVax & $\begin{array}{l}\text { Recombinant NP } \\
\text { profusion spike } \\
\text { protein formulated } \\
\text { with matrix-M } \\
\text { adjuvant }\end{array}$ & USA & 2 doses & 89.3 & $2-8{ }^{\circ} \mathrm{C}$ \\
\hline $\begin{array}{l}\text { BBIBP-CoV vac- } \\
\text { cine }\end{array}$ & Sinopharm & $\begin{array}{l}\text { Inactivated SARS- } \\
\text { CoV-2 vaccine } \\
\text { produced in Vero } \\
\text { cell }\end{array}$ & China & 2 doses & 78.0 & $2-8{ }^{\circ} \mathrm{C}$ \\
\hline
\end{tabular}


the second wave, mainly targeting the younger population with various new unusual symptoms. These variants are found to have much higher transmissibility, making disease spread faster with a much higher positive rate of detection. Nevertheless, with the enhanced resources, the much faster disease spread to put a much higher load on the medical facilities, the oxygen requirement and the requirement of the mechanical ventilator beds were much more than the availability. Even with a much higher positive rate, the death rate was reported to be less than that of the first wave possibly due to vast scientific understanding of the disease and its presentation with many available drugs and approved vaccines, higher availability of medical infrastructure and facilities [28].

\section{Preventive measures and treatment remedies}

Protection is of utmost importance in respiratory viral infections such as SARS-CoV-2, which is highly pathogenic. To protect people from COVID-19, one must follow the guidelines from the health authority and take mandatory steps to prevent the spread of COVID-19 disease. Generally, precautions at the personal level include the use of masks in crowded places, regular hand washing, and better ventilation in indoor spaces. Maintaining social distancing at least 3 feet between two individuals is important when a person is ill or suspected to be ill. Public transport, crowded places, and large public gatherings need to be avoided to stay safe. Various approved vaccines with high efficacy are available, so vaccination is a must as a preventive measure (Table 2) [96].

For protection, disinfection, and immunization purposes, various synthetic polymers such as polystyrene and polylactic acid, in addition to the natural polymers from algae and plants such as chitosan and sodium alginate, are used to fabricate and design diverse protective equipment, antiviral spray, and immunosensors to control and fight against the COVID-19 pandemic spread [29]. Strict compliance is a must and hesitation for vaccination should be avoided. At least vaccination of $60 \%$ of the population is mandatory to reach herd immunity. At the public health level, contact tracing, testing, and isolation of positive cases would be beneficial in controlling the spread of the new emerging variants.

Monoclonal antibodies like bamlanivimab, etesevimab, and REGN-CoV2 are US-FDA approved under emergency use authorization (EUA) to treat mild to moderate patients suffering from SARS-CoV-2 infection. $700 \mathrm{mg}$ bamlanivimab in combination with $1400 \mathrm{mg}$ etesevimab is an authorized dose especially for adults and paediatric patients [97]. These MAb target overlapping epitopes in the RBD of spike protein, thereby preventing the entry of the virus inside the cell. MAb regdanvimab (CT-P59) demonstrated strong neutralizing capacity against the Delta variant, B.1.617.2, in pre-clinical in vivo study and against Lambda variant in the cell-based pseudovirus assay. Regdanimab binds to the RBD of S protein of SARS-CoV- 2 with $K_{\mathrm{d}}=0.065 \mathrm{nM}$ and inhibits the interaction between RBD and ACE- 2 by blocking cellular entry [98]. Significant reduction in SARS-CoV-2 load and inflammation in the lungs result in a $100 \%$ survival rate from COVID-19. Among antivirals, the most widely used drug is remdesivir which inhibits the viral RNAdependent RNA polymerase and is approved by US-FDA for EUA in adults and paediatric patients with severe symptoms. However, traditional medicines practiced in China, India, and Thailand have a short-term effect on COVID-19. China treated $85 \%$ of the COVID-19 patients using traditional medicines such as root extract of Isatis indigotica and extract of Houttuynia cordata [99, 100].

\section{India in action: INSACOG mandate and function}

In India, ICMR developed a diagnostic centre for SARSCoV-2 in NIV-Pune on January 21, 2020 [101]. However, the first Indian case of COVID-19 was reported on Jan 30, 2020, from Kerala. To address the upcoming pandemic, India established 13 VRDLs for COVID-19 testing. Subsequently, on March 13, 2020, SARS-CoV-2 was isolated and genome sequencing was done for the first time in India. Till July 22, India tested 45,29,39,545 samples and administered 42,34,17,030 vaccine doses [101] ("Vaccine information, ICMR New Delhi-Vaccine information, ICMR New Delhi," n.d.).

To counteract the unprecedented public health challenge, Govt. of India established Indian SARS-CoV-2 Genomics Consortium (INSACOG) on 30th December 2020, currently working with the capacity of 28 Genome Sequencing Laboratories (GSLs) to monitor genomic variations in SARSCoV-2 [103]. The whole-genome sequencing facility aids our understanding of the SARS-CoV-2 mutations and evolution. These initiatives may help in curbing and managing the COVID-19 menace effectively.

\section{Conclusion}

The world has already seen enough deaths due to the coronavirus disease that people want this nightmare to be over as soon as possible, yet the SARS-CoV-2 seems to have another plan. The new variants are loaded with various critical mutations in the spike protein, making them more transmissible, infective, spreadable, and lethal. In India, even with the increased resources authorized to fight COVID-19, the actual scenario was much more brutal than anticipated. The Delta 
Plus variant is likely to bring the third wave of coronavirus disease in India, as the cell-to-cell transfer mechanism is likely to reduce the immune actions effectiveness significantly. The virus is likely to spread more effortlessly in the infected individual, making the whole situation more lethal. Further new variants evolving in the lineage of Delta Plus variant are likely to develop symptoms more life threatening instead of focusing on immune escape, as that change has already been made. Diversification of the virus is likely to create more havoc in the third wave of the pandemic. Precautions must be strictly imposed to reduce the casualties, and the focus should be shifted towards confining the infected individuals as rapidly as possible. Being a third-world country, India has better chances to survive by taking the right action and decisions towards preventing the spread of pandemic than to fight for the treatment. Even with increased resources allocated, the second wave of the pandemic has already taught a harsh lesson in fighting against the coronavirus disease.

Acknowledgements The authors would like to thank the Indian Council of Medical Research (ICMR), New Delhi, and PGIMER for financial support to Dr. Vikram Thakur with Junior/Senior Research Fellowship (3/1/3/JRF/2015/HRD/10976/18). The authors also offer special thanks to Prof. Prem Kumar Khosla, Vice-Chancellor, Shoolini University, Solan, for providing financial support and necessary facilities.

Author contributions Vikram Thakur: conceptualization, data curation, formal analysis, writing-original draft, writing-review and editing, validation; Shivam Bhola: conceptualization, data curation, formal analysis, writing - original draft, writing - review and editing, validation; Pryanka Thakur: conceptualization, data curation, formal analysis, writing — original draft, writing — review and editing, validation; Sanjay Kumar Singh Patel: data curation, formal analysis, validation; Sourabh Kulshrestha: data curation, formal analysis, validation; Radha Kanta Ratho: formal analysis, writing - review and editing, validation; Pradeep Kumar: conceptualization, formal analysis, writing-review and editing, validation.

Funding This research did not receive any specific grant from funding agencies in the public, commercial, or not-for-profit sectors.

Availability of data and material Not applicable.

Code availability Not applicable.

\section{Declarations}

Conflict of interest The authors have no relevant financial or non-financial interests to disclose.

Ethics approval Not Applicable.

\section{References}

1. WHO Coronavirus (COVID-19) Dashboard. WHO (2021). https://covid19.who.int/. Accessed 10 July 2021.
2. Mathieu E, Ritchie H, Ortiz-Ospina E, et al. A global database of COVID-19 vaccinations. Nat Hum Behav. 2021. https://doi. org/10.1038/S41562-021-01122-8 (Epub ahead of print 2021).

3. Zhou P, Yang XL, Wang XG, et al. A pneumonia outbreak associated with a new coronavirus of probable bat origin. Nature. 2020;579:270-3.

4. Chan JF, Kok KH, Zhu Z, et al. Genomic characterization of the 2019 novel human-pathogenic coronavirus isolated from a patient with atypical pneumonia after visiting Wuhan. Emerg Microbes Infect. 2020;9:221-36.

5. Tortorici MA, Veesler D. Structural insights into coronavirus entry. Adv Virus Res. 2019;105:93-116.

6. Biswas $\mathrm{S}$, Thakur V, Kaur P, et al. Blood clots in COVID-19 patients: Simplifying the curious mystery. Med Hypotheses. 2021;146:1371.

7. Wan Y, Shang J, Graham R, et al. Receptor recognition by the novel coronavirus from Wuhan: an analysis based on decade-long structural studies of SARS Coronavirus. J Virol. 2020. https:// doi.org/10.1128/JVI.00127-20 (Epub ahead of print 17 March 202).

8. Hoffmann M, Kleine-Weber H, Schroeder S, et al. SARS-CoV-2 cell entry depends on ACE2 and TMPRSS2 and is blocked by a clinically proven protease inhibitor. Cell. 2020;181:271-2808.

9. Thakur V, Ratho RK, Kumar P, et al. Multi-Organ Involvement in COVID-19: beyond pulmonary manifestations. J Clin Med. 2021;10:446.

10. Thakur V, Jain A. COVID 2019-suicides: A global psychological pandemic. Brain Behav Immun. 2020;88:952.

11. Haque SM, Ashwaq O, Sarief A, et al. A comprehensive review about SARS-CoV-2. Future Virol. 2020;15:625.

12. Moreira RA, Guzman HV, Boopathi S, et al. Characterization of structural and energetic differences between conformations of the SARS-CoV-2 spike protein. Materials (Basel). 2020;13:1-14.

13. Park YJ, Walls AC, Wang Z, et al. Structures of MERS-CoV spike glycoprotein in complex with sialoside attachment receptors. Nat Struct Mol Biol. 2019;26:1151-7.

14. Wrapp D, Wang N, Corbett KS, et al. Cryo-EM structure of the 2019-nCoV spike in the prefusion conformation. Science. 2020;367:1255-60.

15. Naqvi AA, Fatima K, Mohammad T, et al. Insights into SARSCoV-2 genome, structure, evolution, pathogenesis and therapies: Structural genomics approach. Biochim Biophys acta Mol basis Dis. 2020. https://doi.org/10.1016/J.BBADIS.2020.165878 (Epub ahead of print 1 October 2020)

16. Menachery VD, Dinnon KH, Yount BL, et al. Trypsin treatment unlocks barrier for zoonotic bat coronavirus infection. J Virol. 2020. https://doi.org/10.1128/JVI.01774-19.

17. Andersen KG, Rambaut A, Lipkin WI, et al. The proximal origin of SARS-CoV-2.

18. Wrobel AG, Benton DJ, Xu P, et al. SARS-CoV-2 and bat RaTG13 spike glycoprotein structures inform on virus evolution and furin-cleavage effects. Nat Struct Mol Biol. 2020;27:763-7.

19. Whittaker GR, Daniel S, Millet JK. Coronavirus entry: how we arrived at SARS-CoV-2. Curr Opin Virol. 2021;47:113-20.

20. Li Q, Wu J, Nie J, et al. The impact of mutations in SARS-CoV-2 spike on viral infectivity and antigenicity. Cell. 2020;182:12841294.e9.

21. Wang MY, Zhao R, Gao LJ, et al. SARS-CoV-2: structure, biology, and structure-based therapeutics development. Front Cell Infect Microbiol. 2020. https://doi.org/10.3389/FCIMB.2020. 587269 (Epub ahead of print 25 November 2020).

22. Cong Y, Feng Y, Ni H, et al. Anchor-locker binding mechanism of the coronavirus spike protein to human ACE2: insights from computational analysis. J Chem Inf Model. 2021. https://doi.org/ 10.1021/ACS.JCIM.1C00241 (Epub ahead of print 22 June 2021). 
23. Korber B, Fischer WM, Gnanakaran S, et al. Tracking changes in SARS-CoV-2 spike: evidence that D614G increases infectivity of the COVID-19 virus. Cell. 2020;182:812-8217.e9.

24. Zhang L, Jackson CB, Mou H, et al. SARS-CoV-2 spikeprotein D614G mutation increases virion spike density and infectivity. Nat Commun. 2020;11:1-9.

25. Lorenzo-Redondo R, Nam HH, Roberts SC, et al. A unique clade of SARS-CoV-2 viruses is associated with lower viral loads in patient upper airways. medRxiv Prepr Serv Health Sci. 2020. https://doi.org/10.1101/2020.05.19.20107144 (Epub ahead of print 26 May 2020).

26. Plante JA, Liu Y, Liu J, et al. Spike mutation D614G alters SARS-CoV-2 fitness. Nature. 2020. https://doi.org/10.1038/ s41586-020-2895-3 (Epub ahead of print 26 October 2020).

27. Mansbach RA, Chakraborty S, Nguyen K, et al. The SARSCoV-2 spike variant D614G favors an open conformational state. Sci Adv. 2021;7(16):eabf3671. https://doi.org/10.1126/ sciadv.abf3671.

28. Jain VK, Iyengar KP, Vaishya R. Differences between First wave and Second wave of COVID-19 in India. Diabetes Metab Syndr. 2021;15:1047.

29. Rosas-Salazar C, Kimura KS, Shilts MH, et al. SARSCoV-2 infection and viral load are associated with the upper respiratory tract microbiome. J Allergy Clin Immunol. 2021;147:1226-1233.e2.

30. Ge X-Y, Li J-L, Yang X-L, et al. Isolation and characterization of a bat SARS-like coronavirus that uses the ACE2 receptor. Nature. 2013;503:535-8.

31. Lai MM, Cavanagh D. The molecular biology of coronaviruses. Adv Virus Res. 1997;48:1-100.

32. Zhao Z, Li H, Wu X, et al. Moderate mutation rate in the SARS coronavirus genome and its implications. BMC Evol Biol. 2004;4:1-9.

33. Parczewski M, Ciechanowicz A. Molecular epidemiology of SARS-CoV-2: a review of current data on genetic variability of the virus. Polish Arch Intern Med. 2020;131:63-9.

34. Singh D, Yi SV. On the origin and evolution of SARS-CoV-2. Exp Mol Med. 2021;53:537-47.

35. SARS-CoV-2 Variant Classifications and Definitions, https:// www.cdc.gov/coronavirus/2019-ncov/variants/variant-info. html. Accessed 10 July 2021.

36. Zhang W, Davis BD, Chen SS, et al. Emergence of a novel SARS-CoV-2 Variant in Southern California. JAMA. 2021;325:1324-6.

37. GISAID - hCov19 Variants, https://www.gisaid.org/hcov19-varia nts/. Accessed 8 July 2021.

38. Deng X, Garcia-Knight MA, Khalid MM, et al. Transmission, infectivity, and antibody neutralization of an emerging SARSCoV-2 variant in California carrying a L452R spike protein mutation. medRxiv Prepr Serv Health Sci. 2021. https://doi.org/ 10.1101/2021.03.07.21252647 (Epub ahead of print 9 March 2021).

39. Garcia-Beltran WF, Lam EC, St Denis K, et al. Multiple SARS$\mathrm{CoV}-2$ variants escape neutralization by vaccine-induced humoral immunity. Cell. 2021;184:2372.

40. McCallum M, Bassi J, De Marco A, et al. SARS-CoV-2 immune evasion by the B.1.427/B.1.429 variant of concern. Science. 2021. https://doi.org/10.1126/SCIENCE.ABI7994 (Epub ahead of print 1 July 2021).

41. Tracking SARS-CoV-2 variants, https://www.who.int/en/activ ities/tracking-SARS-CoV-2-variants/. Accessed 11 July 2021.

42. Chakraborty C, Bhattacharya M, Sharma AR. Present variants of concern and variants of interest of severe acute respiratory syndrome coronavirus 2: Their significant mutations in S-glycoprotein, infectivity, re-infectivity, immune escape and vaccines activity. Rev Med Virol. 2021; p. e2270.
43. FACT SHEET FOR HEALTH CARE PROVIDERS EMERGENCY USE AUTHORIZATION (EUA) OF BAMLANIVIMAB AND ETESEVIMAB AUTHORIZED USE, https://www.cdc.gov/growthcharts/clinical_charts.htm. Accessed 10 July 2021

44. Jangra S, Ye C, Rathnasinghe R, et al. SARS-CoV-2 spike E484K mutation reduces antibody neutralisation. The Lancet Microbe. 2021. https://doi.org/10.1016/S2666-5247(21)00068-9 (Epub ahead of print 1 July 2021).

45. Annavajhala MK, Mohri H, Zucker JE, et al. A novel SARSCoV-2 variant of concern, B.1.526, identified in New York. medRxiv 2021; 2021.02.23.21252259.

46. Zhou H, Dcosta BM, Samanovic MI, Mulligan MJ, Landau NR, Tada T. 2021. B.1.526 SARS-CoV-2 variants identified in New York City are neutralized by vaccine-elicited and therapeutic monoclonal antibodies. mBio 12:e01386-21. https://doi.org/10. 1128/mBio.01386-21.

47. Greaney AJ, Loes AN, Crawford KHD, et al. Comprehensive mapping of mutations in the SARS-CoV-2 receptor-binding domain that affect recognition by polyclonal human plasma antibodies. Cell Host Microbe. 2021;29:463-476.e6.

48. Yadav PD, Sapkal GN, Abraham P, et al. Neutralization Potential of Covishield Vaccinated Individuals Sera Against B.1.617.1, Clinical Infectious Diseases, 2021;, ciab483. https://doi.org/10. 1093/cid/ciab483

49. Romero PE, Dávila-Barclay A, Salvatierra G, et al. The emergence of SARS-CoV-2 variant lambda (C.37) in South America. Microbiol Spectr. 2021. 9:e00789-21. https://doi.org/10.1128/ Spectrum.00789-21.

50. Weekly epidemiological update on COVID-19-29 June 2021, https://www.who.int/publications/m/item/weekly-epidemiolo gical-update-on-covid-19---29-june-2021. Accessed 17 July 2021.

51. Deng X, Garcia-Knight MA, Khalid MM, et al. Transmission, infectivity, and neutralization of a spike L452R SARS-CoV-2 variant. Cell. 2021;184:3426-3437.e8.

52. Greaney AJ, Starr TN, Gilchuk P, et al. Complete mapping of mutations to the SARS-CoV-2 spike receptor-binding domain that escape antibody recognition. Cell Host Microbe. 2021;29:44-57.e9.

53. Wang R, Chen J, Gao K, et al. Vaccine-escape and fast-growing mutations in the United Kingdom, the United States, Singapore, Spain, India, and other COVID-19-devastated countries. Genomics. 2021;113:2158-70.

54. Liu Z, VanBlargan LA, Bloyet LM, et al. Identification of SARSCoV-2 spike mutations that attenuate monoclonal and serum antibody neutralization. Cell Host Microbe. 2021;29:477-488.e4.

55. Harvey WT, Carabelli AM, Jackson B, et al. SARS-CoV-2 variants, spike mutations and immune escape. Nat Rev Microbiol. 2021;19:409-24.

56. Lambda Covid Variant: Lambda, variant of interest, https://india nexpress.com/article/explained/sars-cov-2-coronavirus-lambdavariant-world-health-organization-7392320/. Accessed 8 July 2021.

57. Tada T, Zhou H, Dcosta BM, et al. SARS-CoV-2 Lambda variant remains susceptible to neutralization by mRNA vaccine-elicited antibodies and convalescent serum. bioRxiv. 2021;2021.07.02.450959.

58. About Variants of the Virus that Causes COVID-19 I CDC, https://www.cdc.gov/coronavirus/2019-ncov/variants/variant. html. Accessed 10 July 2021.

59. Weekly epidemiological update - 2 February 2021 , https://www. who.int/publications/m/item/weekly-epidemiological-update---2february-2021. Accessed 17 July 2021.

60. Horby P, Bell I, Breuer J, et al. NERVTAG: Update note on B.1.1.7 severity, 11 February 2021 - GOV.UK. https://www.gov. 
uk/government/publications/nervtag-update-note-on-b117-sever ity-11-february-2021.

61. Vasireddy D, Vasireddy D, Vanaparthy R, et al. Review of COVID-19 Variants and COVID-19 Vaccine Efficacy: What the Clinician Should Know? J Clin Med Res. 2021;13:317-25.

62. Jw T, Pa T, Ds H. Emergence of a new SARS-CoV-2 variant in the UK. J Infect. 2021;82:e27-8.

63. Davies NG, Abbott S, Barnard RC, et al. Estimated transmissibility and impact of SARS-CoV-2 lineage B.1.1.7 in England. Science. 2021; 372, eabg3055. https://doi.org/10.1126/science. $\operatorname{abg} 3055$.

64. Starr TN, Greaney AJ, Hilton SK, et al. Deep mutational scanning of SARS-CoV-2 receptor binding domain reveals constraints on folding and ACE2 binding. Cell. 2020;182:1295-1310.e20.

65. Mccarthy KR, Rennick LJ, Nambulli S, et al. Natural deletions in the SARS-CoV-2 spike glycoprotein drive antibody escape. Science. 2021;371( 6534):1139-1142. https://doi.org/10.1126/ science.abf6950

66. Duchene S, Featherstone L, Haritopoulou-Sinanidou M, et al. Temporal signal and the phylodynamic threshold of SARSCoV-2. Virus Evol. 2020. https://doi.org/10.1093/ve/veaa061/ 5894560 (accessed 8 January 2021).

67. Estimates of severity and transmissibility of novel SARS-CoV-2 variant 501Y.V2 in South Africa I CMMID Repository, https:// cmmid.github.io/topics/covid19/sa-novel-variant.html. Accessed 10 July 2021.

68. Ramanathan M, Ferguson ID, Miao W, et al. SARS-CoV-2 B.1.1.7 and B.1.351 Spike variants bind human ACE2 with increased affinity. The Lancet Infectious Diseases. 2021;21(8):1070. https://doi.org/10.1016/S1473-3099(21) 00262-0.

69. Wise J. Covid-19: The E484K mutation and the risks it poses. BMJ. 2021;372:n359.

70. Tegally H, Wilkinson E, Giovanetti M, et al. Emergence and rapid spread of a new severe acute respiratory syndrome-related coronavirus 2 (SARS-CoV-2) lineage with multiple spike mutations in South Africa. medRxiv. 2020;10: 2020.12.21.20248640.

71. Panzera Y, Goñi N, Calleros L, et al. Genome sequences of SARS-CoV-2 P1 (Variant of Concern) and P2 (Variant of Interest) identified in Uruguay. Microbiol Resour Announc. 2021. https://doi.org/10.1128/MRA.00410-21 (Epub ahead of print 27 May 2021).

72. Faria NR, Mellan TA, Whittaker C, et al. Genomics and epidemiology of the P1 SARS-CoV-2 lineage in Manaus, Brazil. Science (80-). 2021;372:815-21.

73. Sabina EC, Buss LF, Carvalho MPS, et al. Resurgence of COVID-19 in Manaus, Brazil, despite high seroprevalence. Lancet (London, England). 2021;397:452-5.

74. Bhutta ZA, Siddiqi S, Hafeez A, et al. Beyond the numbers: understanding the diversity of covid-19 epidemiology and response in South Asia. https://doi.org/10.1136/bmj.n1544.

75. Mahase E. Covid-19: Delaying end of lockdown will allow more people to be vaccinated, UK government announces. DOI: https://doi.org/10.1136/bmj.n1552.

76. England PH. SARS-CoV-2 variants of concern and variants under investigation in England. Tech Brief 12.

77. Hester Allen A, Vusirikala A, Flannagan J, et al. Increased household transmission of COVID-19 cases associated with SARSCoV-2 Variant of Concern B.1.617.2: a national case-control study. The Lancet Regional Health - Europe. 2021. https://doi. org/10.1016/j.lanepe.2021.100252.

78. Di Giacomo S, Mercatelli D, Rakhimov A, et al. Preliminary report on severe acute respiratory syndrome coronavirus 2 (SARS-CoV-2) Spike mutation T478K. J Med Virol. 2021. https://doi.org/10.1002/JMV.27062.
79. Delta variant triggers dangerous new phase in the pandemic I Science I AAAS, https://www.sciencemag.org/news/2021/06/deltavariant-triggers-dangerous-new-phase-pandemic. Accessed 17 July 2021.

80. Iacobucci G. Covid-19: Single vaccine dose is $33 \%$ effective against variant from India, data show. BMJ. 2021;373:n1346.

81. Jalkanen P, Kolehmainen P, Häkkinen HK, et al. COVID-19 mRNA vaccine induced antibody responses against three SARSCoV-2 variants. Nat Commun. 2021;12:1-11.

82. Positive New Data for Johnson \& Johnson Single-Shot COVID19 Vaccine on Activity Against Delta Variant and Long-lasting Durability of Response I Johnson \& Johnson, https://www.jnj. com/positive-new-data-for-johnson-johnson-single-shot-covid19-vaccine-on-activity-against-delta-variant-and-long-lastingdurability-of-response. Accessed 11 July 2021.

83. Wang Z, Schmidt F, Weisblum Y, et al. mRNA vaccine-elicited antibodies to SARS-CoV-2 and circulating variants. Nature. 2021;592:616-22 (5927855).

84. Abu-Raddad LJ, Chemaitelly H, Butt AA. Effectiveness of the BNT162b2 Covid-19 vaccine against the B.1.1.7 and B.1.351 Variants. N Engl J Med. 2021. https://doi.org/10.1056/NEJMC 2104974 (Epub ahead of print 5 May 2021).

85. Madhi SA, Baillie V, Cutland CL, et al. Efficacy of the ChAdOx1 nCoV-19 Covid-19 vaccine against the B.13.51 variant. N Engl J Med. 2021;384:1885-98.

86. Beta (B.1.351)-GVN. https://gvn.org/covid-19/beta-b-1-351/. Accessed 11 July 2021.

87. Wang P, Casner RG, Nair MS, et al. Increased resistance of SARS-CoV-2 variant P.1 to antibody neutralization. Cell Host Microbe. 2021;29:747-751.e4.

88. Choi B, Choudhary MC, Regan J, et al. Persistence and Evolution of SARS-CoV-2 in an Immunocompromised Host. N Engl J Med. 2020;383:2291-3.

89. Sa K, Da C, Rp D, et al. SARS-CoV-2 evolution during treatment of chronic infection. Nature. 2021;592:277-82.

90. Kupferschmidt K. Mutant coronavirus in the United Kingdom sets off alarms, but its importance remains unclear. Science (80). 2020. https://www.sciencemag.org/news/2020/12/mutantcoronavirus-united-kingdom-sets-alarms-its-importance-remai ns-unclear. Accessed 26 Dec 2020.

91. Munnink BBO, Sikkema RS, Nieuwenhuijse DF, et al. Jumping back and forth: anthropozoonotic and zoonotic transmission of SARS-CoV-2 on mink farms. Science. 2021;371(6525):172-177. https://doi.org/10.1126/science.abe5901.

92. Ferraz MVF, Moreira EG, Coêlho DF, et al. Immune evasion of SARS-CoV-2 variants of concern is driven by low affinity to neutralizing antibodies. Chem Commun. 2021;57:6094-7.

93. Collier DA, De Marco A, Ferreira IATM, et al. Sensitivity of SARS-CoV-2 B117 to mRNA vaccine-elicited antibodies. Nature. 2021;593:136-41

94. Madhi SA, Baillie V, Cutland CL, et al. Efficacy of the ChAdOx1 nCoV-19 Covid-19 vaccine against the B.1.351 variant. N Engl J Med. 2021;384:1885-98. https://doi.org/10.1056/NEJMoa2102 214.

95. Rk G. Will SARS-CoV-2 variants of concern affect the promise of vaccines? Nat Rev Immunol. 2021;21:340-1.

96. Hafeez A, Ahmad S, Siddqui SA, et al. A review of COVID-19 (Coronavirus Disease-2019) diagnosis, treatments and prevention. Eurasian J Med Oncol. 2020;4:116-25.

97. Coronavirus (COVID-19) Update: FDA Authorizes Monoclonal Antibodies for Treatment of COVID-19 I FDA, https://www.fda. gov/news-events/press-announcements/coronavirus-covid-19update-fda-authorizes-monoclonal-antibodies-treatment-covid19-0. Accessed 24 July 2021.

98. Healthcare C, Kft H. MEDICINAL PRODUCT FOR USE $\square$ Name of the medicinal product for Use: Regkirona $\square$ Active 
substance(s): Regdanvimab $\square$ Pharmaceutical form: Concentrate for solution for infusion $\square$ Route of administration: Intravenous infusion $\square$ Strength: $60 \mathrm{mg} / \mathrm{ml}$ 2. NAME AND CONTACT DETAILS OF THE COMPANY.

99. Yang Y, Islam MS, Wang J, et al. Traditional chinese medicine in the treatment of patients infected with 2019-New Coronavirus (SARS-CoV-2): a review and perspective. Int J Biol Sci. 2020;16:1708.

100. Patel SKS, Lee J-K, Kalia VC. Deploying biomolecules as antiCOVID-19 agents. Indian J Microbiol. 2020;60:263.

101. Indian Council of Medical Research, New Delhi, https://www. icmr.gov.in/. Accessed 24 July 2021.
102. Vaccine information, ICMR New delhi - Vaccine information, ICMR New delhi, https://vaccine.icmr.org.in/. Accessed 24 July 2021.

103. Indian SARS-CoV-2 Genomics Consortium (INSACOG) I Department of Biotechnology, https://dbtindia.gov.in/insacog. Accessed 10 July 2021.

104. COVID-19 vaccine tracker I RAPS

105. Status of COVID-19 Vaccines within WHO EUL/PQ evaluation process Manufacturer / WHO EUL holder Name of Vaccine NRA of Record Platform EOI accepted Pre-submission meeting held Dossier accepted for review* Status of assessment** Decision date ${ }^{* * *}$. 